\title{
Acetaminophen metabolites p-aminophenol and AM404 inhibit microglial activation
}

\author{
Wyatt T. Slattery, Andis Klegeris \\ Department of Biology, University of British Columbia Okanagan Campus, Kelowna, BC V1V 1V7, Canada.
}

Correspondence to: Dr. Andis Klegeris, Department of Biology, University of British Columbia Okanagan Campus, Kelowna, BC V1V 1V7, Canada. E-mail: andis.klegeris@ubc.ca

How to cite this article: Slattery WT, Klegeris A. Acetaminophen metabolites p-aminophenol and AM404 inhibit microglial activation. Neuroimmuno/ Neuroinflammation 2018;5:11. http://dx.doi.org/10.20517/2347-8659.2018.05

Received: 17 Feb 2018 First Decision: 16 Mar 2018 Revised: 22 Mar 2018 Accepted: 26 Mar 2018 Published: 12 Apr 2018

Science Editor: Athanassios P. Kyritsis Copy Editor: Jun-Yao Li Production Editor: Cai-Hong Wang

\begin{abstract}
Aim: Alzheimer's disease (AD) is a neurodegenerative disorder characterized by cognitive decline, deposits of amyloid beta and neurofibrillary tangles. Inflammation facilitated by microglia, the resident immune cells of the brain, contribute to the pathogenesis of AD. Epidemiological data indicate that nonsteroidal anti-inflammatory drugs (NSAIDs), which are cyclooxygenase (COX) inhibitors, reduce the risk of developing $A D$ when administered over the course of two or more years. The mechanisms underlying this protective effect are unknown. Acetaminophen (paracetamol), which is not effective as an inhibitor of COX in peripheral tissues, may provide similar protection without the adverse effects of chronic NSAID use. The beneficial effects of acetaminophen have been proposed to stem from its metabolites p-aminophenol and $\mathrm{N}$-arachidonoylaminophenol (AM404), of which, AM404 possesses analgesic and antipyretic properties. The goal of this study was to compare the effects of acetaminophen and its metabolites on microglial immune function and to elucidate the molecular mechanisms engaged by these compounds.
\end{abstract}

Methods: Lipopolysaccharide-stimulated BV-2 murine microglia were used as models. Microglial activation was monitored by their secretion of nitric oxide.

Results: P-aminophenol and AM404 suppressed nitric oxide secretion from stimulated microglia more effectively than acetaminophen through pathways that were independent of COX inhibition, cannabinoid receptor type two (CB2) inhibition, and activation of transient receptor potential cation channel subfamily $\vee$ member 1 (TRPV1).

Conclusion: Since AM404 has been previously demonstrated to attenuate NF-kB activation, it is likely that the protective effects of acetaminophen against adverse microglia activation are mediated by its metabolites p-aminophenol and AM404 inhibiting this transcription factor.

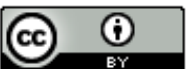

(C) The Author(s) 2018. Open Access This article is licensed under a Creative Commons Attribution 4.0 International License (https://creativecommons.org/licenses/by/4.0/), which permits unrestricted use, sharing, adaptation, distribution and reproduction in any medium or format, for any purpose, even commercially, as long as you give appropriate credit to the original author(s) and the source, provide a link to the Creative Commons license, and indicate if changes were made.

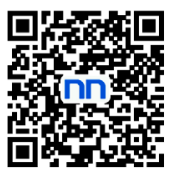


Keywords: Acetaminophen, p-aminophenol, AM404, neuroinflammation, pharmacodynamics, microglia

\section{INTRODUCTION}

Inflammation is believed to contribute to the pathogenesis of Alzheimer's disease $(A D)^{[1,2]}$. Complement protein cascades, cyclooxygenases (COX), oxygen free radical species, cytokines, chemokines, and other inflammatory factors such as acute phase proteins have been linked to the development and progression of $\mathrm{AD}^{[2,3]}$. Release of pro-inflammatory mediators by microglia, the main effector cells of inflammation within the central nervous system (CNS), could be sufficient to cause AD pathology independently of other pathological events, such as deposition of the amyloid $\beta$ protein $(\mathrm{A} \beta)$ and neurofibrillary tangles $(\mathrm{NFT})^{[4,5]}$. Elevated nitric oxide $(\mathrm{NO})$ released by astrocytes and microglia during neurodegenerative disease is both necessary and sufficient to induce primary microglial phagocytosis of neurons and leads to neurotoxic effects resulting from perturbed mitochondrial respiration ${ }^{[6-8]}$. Down-regulation of inducible nitric oxide synthase (iNOS) in AD-model mice, and subsequent decrease in NO, has been associated with rescue of cognitive function, reduction in $A \beta$ and NFT load, decreased glial activation, and attenuated neuronal loss ${ }^{[9-11]}$. As dysregulated activation of microglia resulting from inflammatory insult has been closely associated with $\mathrm{AD}$ brain regions exhibiting extensive deterioration, $\mathrm{A} \beta$ deposition, and markers of NO-mediated protein damage $e^{[8,12,13]}$, it has been suggested that reducing microglial activation may be an effective means of treating neurodegenerative diseases. Epidemiological studies indicate that long-term use of non-steroidal antiinflammatory drugs (NSAIDs), which inhibit microglial COX and their select immune functions, reduces the relative risk of developing $\mathrm{AD}^{[13,14]}$; however, several clinical trials have failed to identify protective activity of NSAIDs in $\mathrm{AD}$ patients ${ }^{[15-17]}$.

While not generally considered an anti-inflammatory drug, acetaminophen (paracetamol, N-acetylpara-aminophenol, APAP) has similar clinical indications to NSAIDs due to its analgesic and antipyretic properties $^{[18]}$. Acetaminophen inhibits the synthesis of prostaglandin (PG) E2, PGF2, and thromboxane B2 by lipopolysaccharide (LPS)-stimulated microglia, yet has no effect on the levels of pro-inflammatory mediators such as tumor necrosis factor (TNF)- $\alpha$ and $\mathrm{NO}^{[19,20]}$. These effects are attributed to the inhibition of COX enzymatic activity, as the expression of the enzymes involved in PG synthesis, including COX, is not affected nor does the concentration of the PG precursor, arachidonic acid, significantly vary with acetaminophen treatment ${ }^{[20]}$. Moreover, the inhibition of COX by acetaminophen has been shown to be more efficacious in microglia than in peripheral macrophages ${ }^{[20,21]}$. It has been suggested that the low levels of oxidants in the CNS potentiate the ability of acetaminophen to reduce the catalytically active oxidized form of COX to its inactive state ${ }^{[21]}$. It has, therefore, been proposed that acetaminophen may be a good agent for treating neuroinflammation in the CNS, without compromising peripheral PG levels ${ }^{[20]}$.

In addition to COX inhibition, the cannabinoid system has been suggested as the possible pharmacological target of acetaminophen. Antagonists of cannabinoid receptors inhibited the analgesic activity of acetaminophen by reducing the responsiveness of mice to nociceptive stimuli, attributable to the modulation of cytokine and NO pathways ${ }^{[22,23]}$. These studies suggest that the therapeutic activity of acetaminophen could be mediated, at least in part, through the effects of the parent drug or its metabolites on the cannabinoid system ${ }^{[24]}$. Studies on pharmacokinetics have indicated that acetaminophen undergoes extensive phase I and phase II metabolism prior to excretion. Initially, it was postulated that acetaminophen is metabolized by sulfotransferases (30\%-44\%) and uridine-5'-diphospho-glucuronosyltransferases $(52 \%-57 \%)$ in the liver to inactive secondary compounds ${ }^{[25]}$. In 2005 , however, an alternative metabolic pathway was described in which acetaminophen undergoes deacetylation to a lipid-soluble intermediate p-aminophenol, catalyzed to some extent by liver acylamidase and $\mathrm{N}$-deacetylase ${ }^{[26-28]}$. Following distribution to the CNS, p-aminophenol is conjugated to arachidonic acid via fatty acid amide hydrolase (FAAH) to form the bioactive $\mathrm{N}$-acylphenolamine, $\mathrm{N}$-arachidonoylaminophenol (AM404) ${ }^{[27-29]}$. A single dose of acetaminophen commonly used to induce analgesia in rats $(300 \mathrm{mg} / \mathrm{kg}$ body weight) leads to 


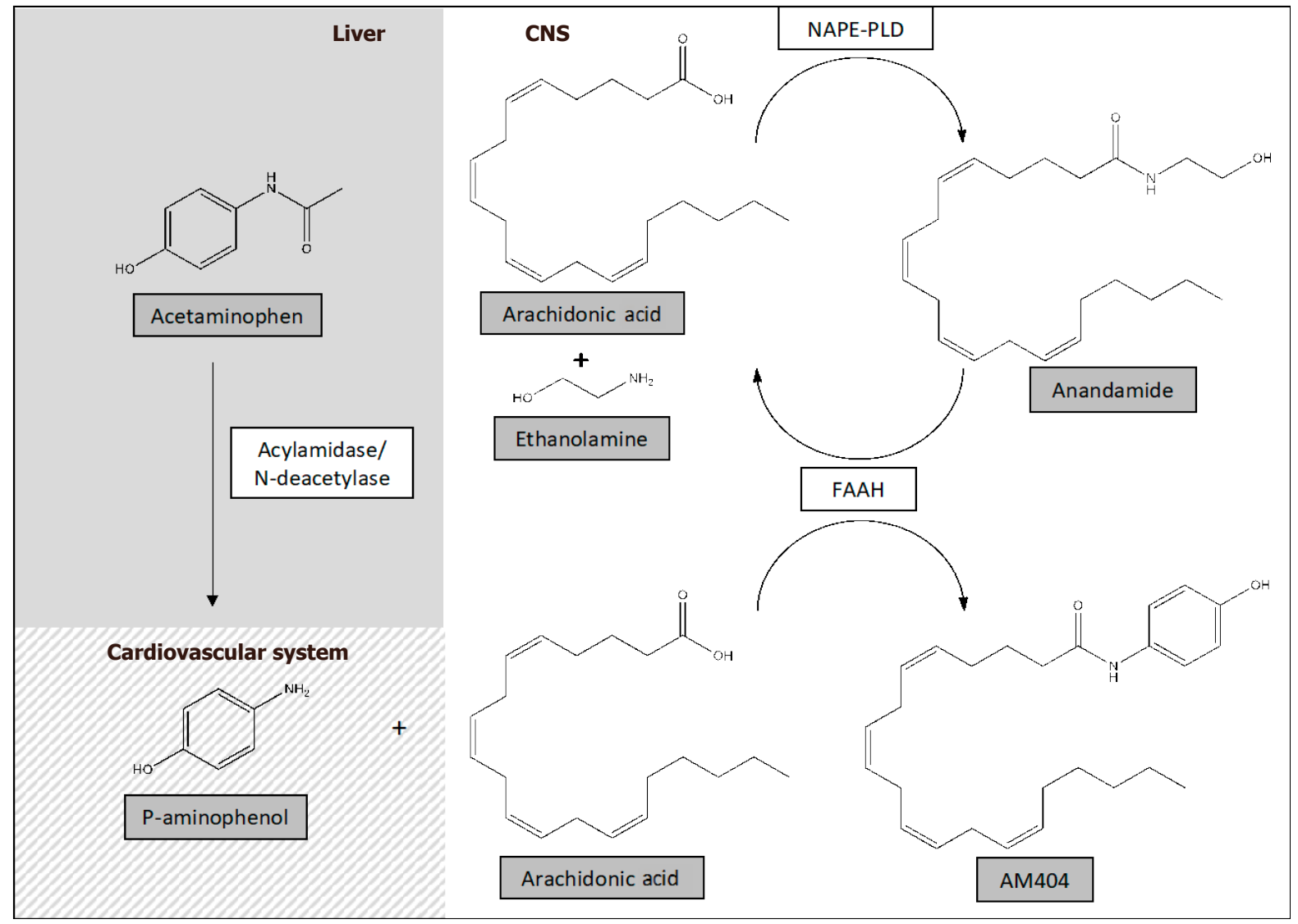

Figure 1. Acetaminophen undergoes deacetylation in the liver (grey) by acylamidase and N-deacetylase to yield p-aminophenol. P-aminophenol is distributed through the cardiovascular system (white/grey) to the central nervous system (CNS) (white). In the CNS, p-aminophenol is conjugated to arachidonic acid by fatty acid amide hydrolase (FAAH) to yield AM404. FAAH also breaks down anandamide to arachidonic acid and ethanolamine. The catabolic activity of FAAH on anandamide is counterbalanced by $\mathrm{N}$-acyl phosphatidylethanolamine phospholipase D (NAPE-PLD), which re-synthesizes anandamide from arachidonic acid and ethanolamine

approximately $7 \mu \mathrm{mol} / \mathrm{L}$ p-aminophenol and $10 \mathrm{nmol} / \mathrm{L}$ AM404 in the brain ${ }^{[27]}$. Figure 1 illustrates the metabolic pathways of acetaminophen from its deacetylation in the liver, to the formation of the bioactive $\mathrm{N}$-acylphenolamine, AM404. The concomitant activity of FAAH in catabolizing the endocannabinoid anandamide (also known as $\mathrm{N}$-arachidonoylethanolamine, AEA) to its metabolites ethanolamine and arachidonic acid is also presented.

Originally reported as an endogenous cannabinoid reuptake inhibitor, AM404 has various roles in nociceptive and thermoregulatory pathways including potentiating the activity of anandamide through inhibition of FAAH, acting as an agonist of the transient receptor potential cation channel subfamily $\mathrm{V}$ member 1 (TRPV1), inhibiting enzymatic activity of the two COX isoforms (COX-1 and COX-2), and preventing NF$\kappa \mathrm{B}$ activation ${ }^{[27,30]}$. Upon the discovery that $\mathrm{AM} 404$ is a bioactive metabolite of acetaminophen, it was hypothesized that AM404 may be responsible for some of the pharmacological activities of acetaminophen in vivo. Several studies have since confirmed that AM404 contributes to the analgesic, antinociceptive, and anxiolytic activities of acetaminophen through its effects on cannabinoid receptor type $1(\mathrm{CB} 1)$ and $\mathrm{FAAH}^{[2,31,32]}$. In mice, acetaminophen exerts an AM404-mediated anxiolytic effect that is dependent on CB1 signaling. Other studies have identified that the metabolites of acetaminophen, $\mathrm{p}$-aminophenol or $\mathrm{AM} 404$, can indirectly activate $\mathrm{CB} 1$ receptors by inhibiting cellular uptake of the endogenous $\mathrm{CB} 1$ receptor agonist anandamide ${ }^{[32,33]}$. Additionally, FAAH inhibition has recently been described to initiate protective responses in neurodegenerative diseases, alleviating oxidative damage in the hippocampus and frontal 
cortex $^{[34]}$. In summary, some of the pharmacological activity of acetaminophen is mediated by its bioactive metabolites p-aminophenol and AM404. It is currently unknown whether p-aminophenol and AM404 have protective effects beyond COX inhibition that may indicate the use of acetaminophen as an effective means of treating neurodegenerative diseases. Due to resounding evidence that NO contributes directly to the pathogenesis of $\mathrm{AD}$, this study evaluated the possible beneficial effects of acetaminophen and its metabolites in the neurodegenerative disease pathology as inhibitors of the release of NO from activated microglia.

\section{METHODS}

\section{BV-2 cell culture}

BV-2 cells were suspended at 0.2 million cells $/ \mathrm{mL}$ in Dulbecco's Modified Eagle's Medium/F12 containing $100 \mathrm{U} / \mathrm{mL}$ penicillin, $100 \mu \mathrm{g} / \mathrm{mL}$ streptomycin and 5\% calf bovine serum (F5) (all from Fisher Scientific, Ottawa, ON, Canada). Two $\mathrm{mL}$ of cell suspension were added to each well of a 24 -well plate (Corning Inc., Corning, NY, USA) and incubated for $24 \mathrm{~h}$ at $37^{\circ} \mathrm{C}$ in $5 \% \mathrm{CO}_{2}$ to allow for adherence. Cells were treated with various concentrations of URB597 or 4-(3-chloro-2-pyridinyl)-N-[4-(1,1-dimethylethyl)phenyl]1-piperazinecarboxamide (BCTC) (0.02, 0.5, $2 \mu \mathrm{mol} / \mathrm{L}$, Cayman Chemical Company, Ann Arbor, MI, USA), SR144528 (0.02, 0.5, $2 \mu \mathrm{mol} / \mathrm{L}$, EMD Millipore, Etobicoke, ON, Canada), indomethacin (2, 20, 50 $\mu \mathrm{mol} / \mathrm{L}$, Sigma-Aldrich, Oakville, ON, Canada), or vehicle solution ( $0.1 \%$ dimethyl sulfoxide, DMSO) and incubated for $15 \mathrm{~min}$ at $37{ }^{\circ} \mathrm{C}$ in $5 \% \mathrm{CO}_{2}$. BV-2 cells were subsequently treated with various concentrations $(2,20,50 \mu \mathrm{mol} / \mathrm{L})$ of acetaminophen (MP Biomedicals, Solon, OH, USA), p-aminophenol (Sigma-Aldrich), AM404 (Cayman), or vehicle solution (0.1\% DMSO) and incubated for a further 15 min period under the same conditions. Subsequently, BV-2 cells were stimulated with LPS $(0.5 \mu \mathrm{g} / \mathrm{mL}$, Sigma-Aldrich) for $24 \mathrm{~h}$ to induce NO secretion. In our experiments, the specific inhibitors URB597, BCTC, and SR144528 were used at concentrations at least ten times higher than their reported IC50 values, thus ensuring inhibition of their respective targets.

\section{Griess assay for nitrite detection}

Secretion of NO by murine BV-2 cells was quantified indirectly by measuring the accumulation of its stable breakdown product, nitrite ${ }^{[35-38]}$. Briefly, $50 \mu \mathrm{L}$ of cell culture supernatant from each well of a 24 -well plate were transferred to a 96-well plate. $50 \mu \mathrm{L}$ sodium nitrite solutions in F5 (0.1-40 $\mu \mathrm{mol} / \mathrm{L})$ were also added to the 96-well plate. An equal volume of Griess reagent, prepared immediately beforehand by combining $1 \%$ sulfanilamide, $0.1 \% \mathrm{~N}$-(1-naphthyl)ethylenediamine dihydrochloride, and 2.5\% phosphoric acid (all from Sigma-Aldrich) was then added to each well and absorbance at $570 \mathrm{~nm}$ was measured. Absorbance values for test wells were normalized relative to control supernatants obtained from unstimulated BV-2 cells and nitrite concentration was calculated from the standard curve obtained by using solutions of sodium nitrite at different concentrations.

\section{Lactate dehydrogenase cytotoxicity assay}

Cellular death results in the loss of cell membrane integrity and an uncontrolled release of intracellular components into the extracellular space, including the release of cytoplasmic lactate dehydrogenase $(\mathrm{LDH})$. Activity of this enzyme can be quantified to measure the extent of cell death ${ }^{[39]}$. Briefly, $100 \mu \mathrm{L}$ of cell-free supernatant from each well of a 24 -well plate were transferred to a 96 -well plate and $20 \mu \mathrm{L}$ of iodonitrotetrazolium chloride ( $4 \mathrm{mg} / \mathrm{mL}$, Sigma-Aldrich) were added to each well. Absorbance was measured at $490 \mathrm{~nm}$. Next, a solution was prepared consisting of lactate $(750 \mu \mathrm{g} / \mathrm{mL}), \beta$-nicotinamide adenine dinucleotide $(60 \mu \mathrm{g} / \mathrm{mL})$, and diaphorase $(55 \mu \mathrm{g} / \mathrm{mL})$ (all from Sigma-Aldrich) in phosphate-buffered saline (PBS); $30 \mu \mathrm{L}$ of the solution were added to each well and absorbance was measured at $490 \mathrm{~nm}$ following a 30-min incubation at $37^{\circ} \mathrm{C}$. Cell death was calculated as a percent relative to total LDH level measured in cultures of untreated cells lysed with $1 \%$ Triton X-100 (100\% lysed cells). 


\section{MTT cell viability assay}

MTT is a water-soluble tetrozolium dye that is converted by the mitochondrial enzyme succinate dehydrogenase to an insoluble purple formazan in live cells. Spectrophotometric quantification of formazan dye present in the cells allows for determination of cell viability ${ }^{[40]}$. The MTT assay is more sensitive in detecting cytotoxicity when compared with the LDH assay; however, it may also incorrectly report mitochondrial dysfunction as cell death ${ }^{[1,42]}$. Therefore, the MTT and the LDH assays were used in parallel in this study. The MTT cell viability assay was conducted by, first, adding MTT (Sigma-Aldrich) to the cell cultures in a 24 -well plate to reach a final concentration of $500 \mu \mathrm{g} / \mathrm{mL}$. Plates were incubated for $1 \mathrm{~h}$ at $37^{\circ} \mathrm{C}$ in $5 \% \mathrm{CO}_{2}$ to allow for cellular metabolism of the tetrozolium dye. Then $20 \%$ sodium dodecyl sulfate $/ 50 \%$ N,N-dimethylformamide (both from Fisher Scientific) solution in milliQ water (EMD Millipore) was added 1:1 to the cell culture in each well to lyse the cells and solubilize the formazan crystals. Plates were incubated overnight at $37^{\circ} \mathrm{C}$ until the crystals dissolved and absorbance of each sample was measured at $570 \mathrm{~nm}$. Cellular viability was calculated as a percent relative to fully viable cells incubated in fresh cell culture media only.

\section{Statistical analysis}

Data were analyzed with Prism V7.0c (Graphpad Software, Inc., USA). One-way and two-way analyses of variance (ANOVA) were performed, followed by Dunnett's post hoc test and Tukey's honestly-significant difference (HSD) test, respectively. Data are presented as means \pm standard error of the mean (SEM). $P$-values less than 0.05 were considered statistically significant.

\section{RESULTS}

The aim of this study was to determine whether the inhibitory effects of acetaminophen on microgliadriven inflammation are mediated by the parent acetaminophen molecule or its metabolites, $\mathrm{p}$-aminophenol and AM404. BV-2 microglial cells were used, which is a widely-accepted model of primary microglia ${ }^{[36]}$. Their activation was induced by LPS, which, similar to several endogenous pro-inflammatory molecules, triggers expression of inducible nitric oxide synthase (iNOS), leading to release of neurotoxic concentrations of NO by microglia ${ }^{[43-46]}$.

Clinically, acetaminophen is indicated for treatment of fever and pain. It has been reported to affect several microglial functions in vitro. In LPS-stimulated microglia, acetaminophen suppressed the synthesis of the inflammatory mediators PGE2, PGF2, and thromboxane B2 by inhibiting the activity of COX; however, it had no effect on the levels of the pro-inflammatory mediators TNF- $\alpha$ and $\mathrm{NO}^{[19,20]}$. Data in Figure $2 \mathrm{~A}$ confirm these observations by showing that at therapeutic as well as supratherapeutic concentrations acetaminophen had no significant effect on NO released by LPS-stimulated BV-2 microglia. Both metabolites of acetaminophen studied, p-aminophenol and AM404, at 20 and $50 \mu \mathrm{mol} / \mathrm{L}$ significantly inhibited this parameter of microglial activation [Figure $2 \mathrm{~B}$ and $\mathrm{C}$ ]. It is important to note that at the concentrations studied none of the three compounds reduced the viability of BV-2 cells, relative to vehicletreated control cells, measured by the LDH [Figure 3] and MTT assays [Figure 4]. Stimulation of BV-2 cells by LPS causes significant increase in cell death (30\%-40\% cell death, Figure 3$)$ and reduction in cell viability (50\%-80\% cell viability, Figure 4 ) in the absence of any of the compounds studied. Adding acetaminophen, p-aminophenol or AM404 did not lead to further enhancement of the LPS-induced cell death. Because nontoxic concentrations of inhibitors were used, it was concluded that the observed decreases in NO secretion by stimulated BV-2 microglia were caused by inhibition of specific signaling pathways.

Previous reports have suggested that at least some of the clinical effects of acetaminophen could be due to its metabolism to AM404 or the deacetylated intermediate, p-aminophenol ${ }^{[47]}$. Following distribution to the CNS, p-aminophenol is conjugated to arachidonic acid through the catalytic activity of FAAH, 
A

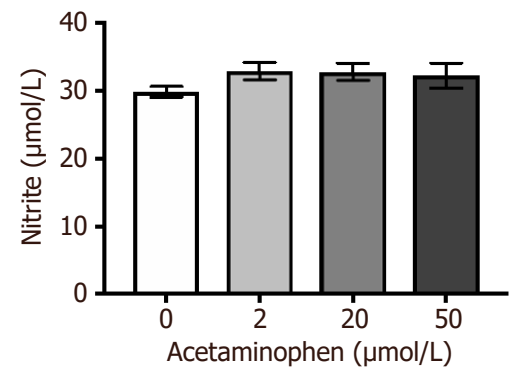

B

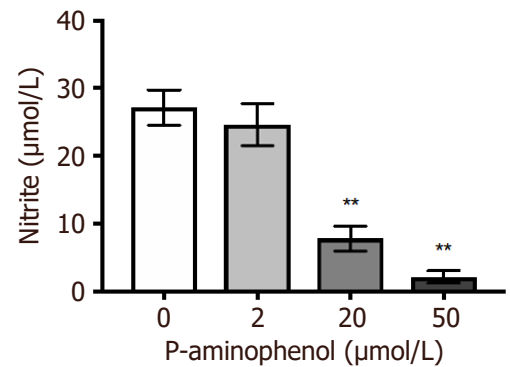

\section{C}

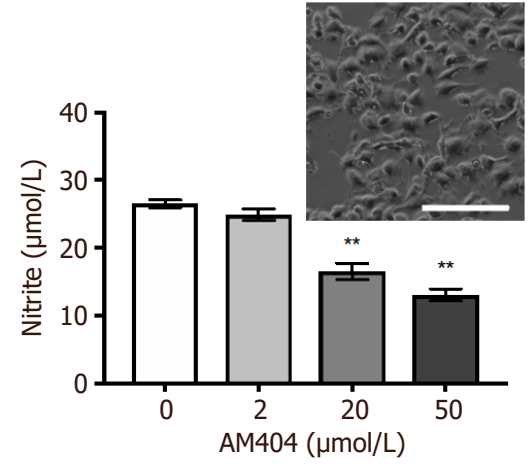

Figure 2. Effects of acetaminophen (A), p-aminophenol (B), and AM404 (C) on lipopolysaccharide (LPS)-induced nitric oxide release. BV-2 cells were treated with various concentrations of drugs $(2,20,50 \mu \mathrm{mol} / \mathrm{L})$ for $15 \mathrm{~min}$, then stimulated with LPS. Nitrite concentrations in BV-2 cell-free supernatants were measured after 24 h using the Griess assay. Data (means \pm SEM) from 3-5 independent experiments are presented. The effects of the treatments were assessed by the one-way analyses of variance (ANOVA), followed by Dunnett's post hoc test. ${ }^{\star \star} P<0.01$, significantly different from stimulated control cells incubated in the absence of drugs. $F$ and $P$ values for the main effects of one-way ANOVA are: (A) $F=1.09, P=0.41$; (B) $F=29.33, P<0.0001$; (C) $F=50.28, P<0.0001$. Insert in (C) is a phase-contrast image of LPS-stimulated BV-2 microglia (scale bar $=200 \mu \mathrm{m})$

A

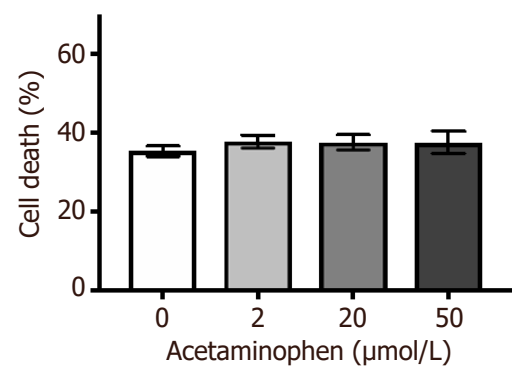

B

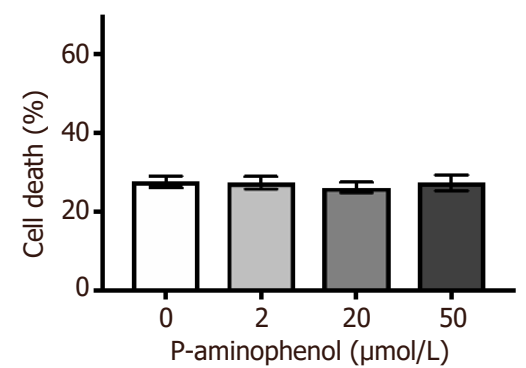

C

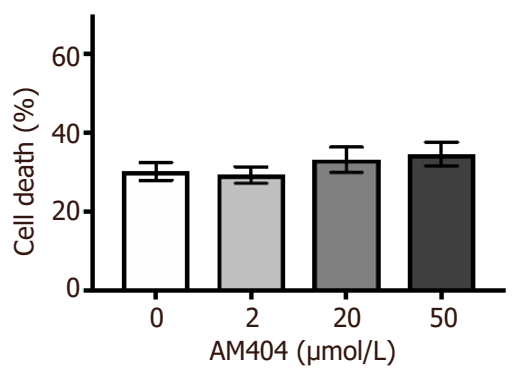

Figure 3. Effects of acetaminophen (A), p-aminophenol (B), and AM404 (C) on lipopolysaccharide (LPS)-induced cell death. BV-2 cells were treated with various concentrations of drugs $(2,20,50 \mu \mathrm{mol} / \mathrm{L})$ for $15 \mathrm{~min}$, then stimulated with LPS. Following $24 \mathrm{~h}$ incubation, cell death was measured using the LDH assay. Data (mean \pm SEM) from 3-5 independent experiments are presented. The effects of the treatments were assessed by the one-way analyses of variance (ANOVA), followed by Dunnett's post hoc test. No significant differences were observed. $F$ and $P$ values for the main effects of one-way ANOVA are: $(A) F=0.31, P=0.82$; $(B) F=0.17, P=0.92 ;(C) F=0.84, P=0.48$

A

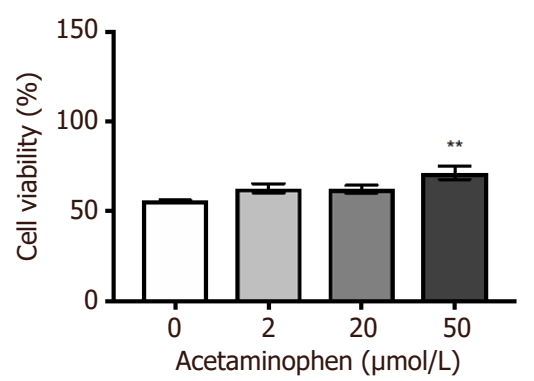

B

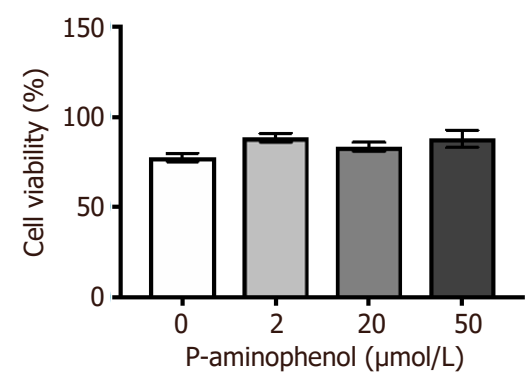

C

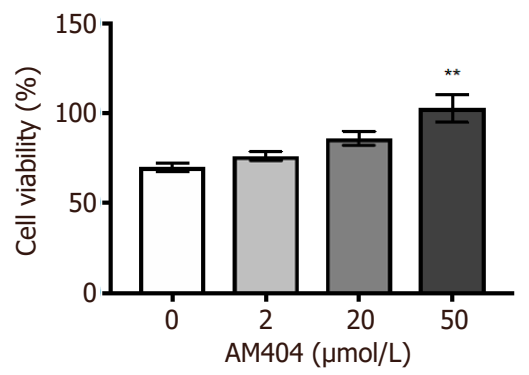

Figure 4. Effects of acetaminophen (A), p-aminophenol (B), and AM404 (C) on lipopolysaccharide (LPS)-induced cell viability. BV-2 cells were treated with various concentrations of drugs $(2,20,50 \mu \mathrm{mol} / \mathrm{L})$ for $15 \mathrm{~min}$, then stimulated with LPS. Following $24 \mathrm{~h}$ incubation, cell viability was measured using the MTT assay. Data (mean \pm SEM) from 3-5 independent experiments are presented. The effects of the treatments were assessed by the one-way analyses of variance (ANOVA), followed by Dunnett's post hoc test. ${ }^{* \star} P<0.01$, significantly different from stimulated control cells incubated in the absence of drugs. $F$ and $P$ values for the main effects of one-way ANOVA are: (A) $F=6.09, P=0.018 ;(B) F=2.51, P=0.066$; (C) $F=9.39, P=0.0001$ 


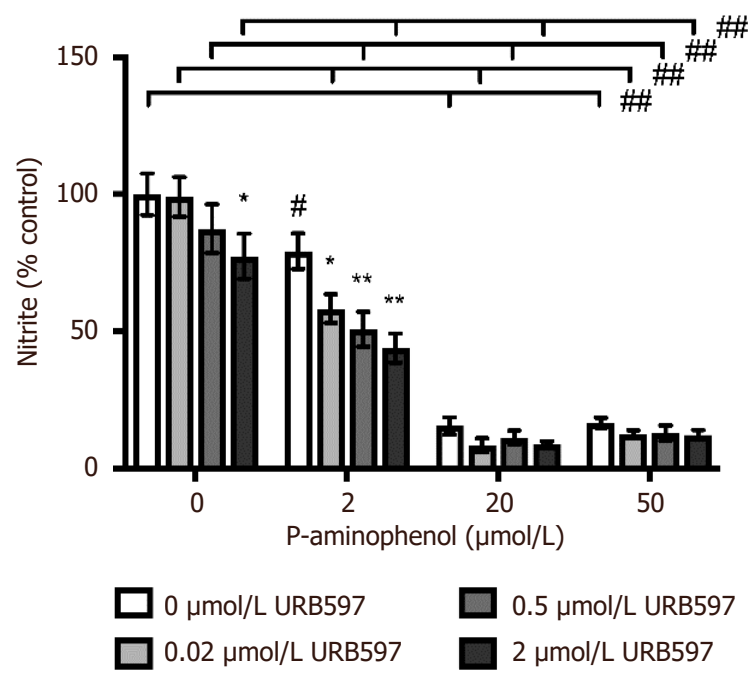

Figure 5. Effects of $p$-aminophenol alone, or in combination with the fatty acid amide hydrolase inhibitor URB597, on the lipopolysaccharide (LPS)-induced nitric oxide release. BV-2 cells were treated for $15 \mathrm{~min}$ with various concentrations of URB597 (0.02, 0.5, $2 \mu \mathrm{mol} / \mathrm{L})$, then incubated with different concentrations $(2,20,50 \mu \mathrm{mol} / \mathrm{L})$ of $\mathrm{p}$-aminophenol for a further $15 \mathrm{~min}$ period, before being stimulated with LPS. After $24 \mathrm{~h}$, nitrite concentrations in the BV-2 cell-free supernatants were measured using the Griess assay. Data from nine independent experiments are normalized against nitrite concentration in samples stimulated in the absence of inhibitors. Nitrite concentration in these samples was $13.2 \pm 1.0 \mu \mathrm{mol} / \mathrm{L}$. The effect of treatments was assessed by the two-way analyses of variance (ANOVA), followed by Tukey's post hoc test. ${ }^{\star} P<0.05$ and ${ }^{\star \star} P<0.01$, significantly different from stimulated cells incubated in the absence of URB597 (ANOVA $F=7.87$, $P<0.0001$ ); ${ }^{\#} P<0.05$ and ${ }^{\# \#} P<0.01$, significantly different from stimulated cells incubated in the absence of $p$-aminophenol (ANOVA $F=$ 216.2, $P<0.0001$ ). ANOVA interaction $F=1.83, P=0.068$

forming AM404 ${ }^{[27]}$. In the CNS, AM404 activates TRPV 1 but inhibits COX-1 and COX-2 enzymatic activity, anandamide reuptake and metabolism, as well as the transcription factors NF- $\kappa \mathrm{B}$ and nuclear factor of activated T-cells (NFAT) ${ }^{[2,30]}$. Due to these various pharmacological activities, AM404 has been implicated as the active substance responsible for the clinically beneficial effects of acetaminophen on nociception, mechanical allodynia, thermal hyperalgesia, as well as inflammatory processes resulting from the gene activation induced by the transcription factors NF- $\mathrm{B}$ and NFAT. Specifically, the ability of AM404 to alleviate neuropathic pain in rodent models has been attributed to a reduction in NO and cytokine production $^{[23]}$. In this study, we report that AM404 suppresses NO secretion by LPS-stimulated BV-2 cells [Figure $2 \mathrm{C}$ ].

Since both p-aminophenol and AM404 effectively reduced NO release by stimulated BV-2 microglia, we hypothesized that FAAH present in BV-2 cells may allow p-aminophenol to exert its effect on microglial activation through its metabolism to $\mathrm{AM} 404^{[48]}$. To test this hypothesis, BV-2 cells were incubated with various concentrations $(0.02,0.5,2 \mu \mathrm{mol} / \mathrm{L})$ of the specific FAAH inhibitor URB597 for 15 min prior to treatment with $\mathrm{p}$-aminophenol. We rationalized that the inhibitory effect of $\mathrm{p}$-aminophenol would be eliminated in the presence of URB597, if this metabolite were working through its conversion to AM404. As illustrated in Figure 5, p-aminophenol attenuated NO secretion from stimulated microglia in the presence of all concentrations of URB597 tested. Interestingly, URB597 itself showed an inhibitory effect on NO release in the absence of $\mathrm{p}$-aminophenol and in the presence of $2 \mu \mathrm{mol} / \mathrm{L} \mathrm{p}$-aminophenol. These results indicate that, contrary to the initial hypothesis, $\mathrm{p}$-aminophenol inhibits $\mathrm{NO}$ secretion through a pathway independent of its conversion to AM404 by FAAH. Moreover, p-aminophenol and URB597 may act synergistically to abate microglial activation.

It has been suggested that URB597 may function to attenuate microglial activation through the inhibition of $\mathrm{FAAH}^{[49]}$. In addition to catalyzing the conjugation of $\mathrm{p}$-aminophenol and arachidonic acid, FAAH functions in the degradation of fatty acid amides such as the endocannabinoid anandamide ${ }^{[50]}$. In this 


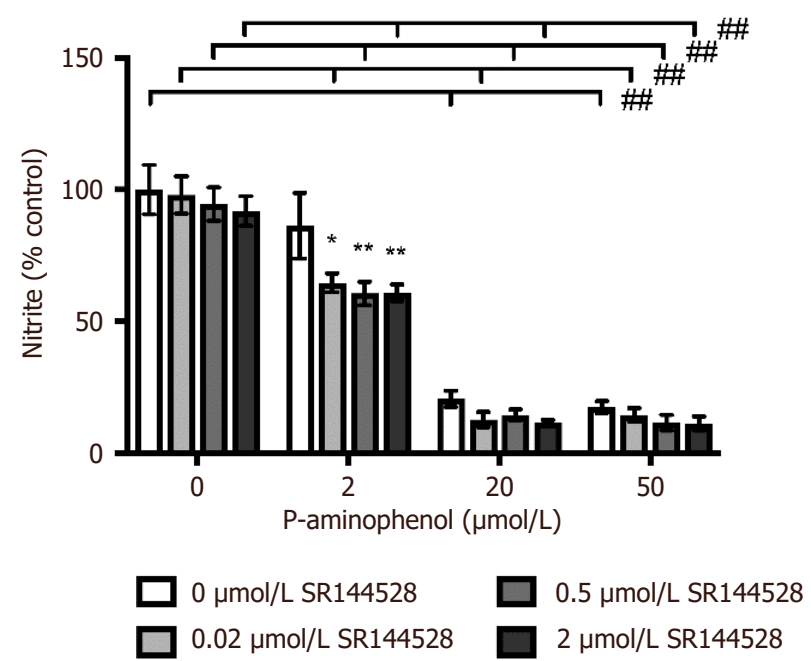

Figure 6. Effects of p-aminophenol alone or in combination with the selective CB2 receptor antagonist SR144528 on lipopolysaccharide (LPS)-induced nitric oxide release. BV-2 cells were treated for $15 \mathrm{~min}$ with various concentrations of SR144528 $(0.02,0.5,2 \mu \mathrm{mol} / \mathrm{L})$, then incubated with different concentrations $(2,20,50 \mu \mathrm{mol} / \mathrm{L})$ of $\mathrm{p}$-aminophenol for a $15 \mathrm{~min}$ period, before being stimulated with LPS. After $24 \mathrm{~h}$, nitrite concentrations in the BV-2 cell-free supernatants were measured using the Griess assay. Data from four independent experiments are normalized against nitrite concentration in samples stimulated in the absence of inhibitors. Nitrite concentration in these samples was $19.6 \pm 1.8 \mu \mathrm{mol} / \mathrm{L}$. The effect of treatments was assessed by the two-way analyses of variance (ANOVA), followed by Tukey's post hoc test. ${ }^{\star} P<0.05$ and ${ }^{\star *} P<0.01$, significantly different from stimulated cells incubated in the absence of SR144528 (ANOVA $F=4.17, P=0.011) ; \# P<0.01$, significantly different from stimulated cells incubated in the absence of $p$ aminophenol (ANOVA $F=232.2$, $P<0.0001)$. ANOVA interaction $F=0.79, P=0.62$

capacity, URB597 indirectly activates cannabinoid receptors by potentiating the effect of bioavailable anandamide. Similarly, it has been identified that AM404 inhibits anandamide reuptake and degradation through mechanisms which are currently unknown ${ }^{[51,52]}$. Accordingly, it has been reported that URB597 and AM404 have similar effects on LPS-induced inflammation in rats that are CB1 and CB2 receptor dependent ${ }^{[53]}$. These observations are consistent with our data showing that URB597 on its own [Figure 5], similar to AM404 [Figure 2C], inhibits nitrite secretion by BV-2 microglia.

Next, we investigated the role of cannabinoid receptor signaling in mediating the effect of p-aminophenol and AM404 on NO secretion by LPS-stimulated microglia. Controversy exists surrounding the ability of AM404 to directly bind and activate CB1 receptors; however, it is widely agreed that AM404 attenuates the reuptake and degradation of the endogenous cannabinoid, anandamide, thereby potentiating its agonistic effect at $\mathrm{CB} 1$ and $\mathrm{CB} 2$ receptors $^{[23]}$. Moreover, it has been suggested that AM404-mediated activation of TRPV1 is sufficient to induce the synthesis of additional anandamide, further increasing signaling through both $\mathrm{CB} 1$ and $\mathrm{CB} 2$ receptors ${ }^{[54]}$. It has been previously reported that signaling through $\mathrm{CB} 1$ receptors has neurotoxic and psychoactive effects, while signaling through $\mathrm{CB} 2$ receptors reduces the toxicity of the LPS-stimulated microglia ${ }^{[55]}$. As BV-2 cells express functionally active CB2 receptors, we determined whether the effect of $\mathrm{p}$-aminophenol and AM404 on microglial activation was mediated by $\mathrm{CB} 2$ receptor signaling ${ }^{[56-58]}$. Microglia were incubated with various concentrations of the selective $\mathrm{CB} 2$ receptor antagonist SR144528 $(0.02,0.5,2 \mu \mathrm{mol} / \mathrm{L})$ for $15 \mathrm{~min}$ prior to treatment with p-aminophenol or AM404. Figures 6 and 7 indicate that CB2 receptor blockade did not reduce the secretion of NO from LPSstimulated BV-2 cells in the absence of p-aminophenol and AM404. SR144528 also did not attenuate the inhibitory effects of p-aminophenol [Figure 6] or AM404 [Figure 7]; however, treatment with SR144528 did inhibit NO secretion in the presence of $2 \mu \mathrm{mol} / \mathrm{L} \mathrm{p}$-aminophenol [Figure 6]. These data indicate that neither AM404 nor p-aminophenol exert their effect on NO production by BV-2 cells through engaging the $\mathrm{CB} 2$ receptor and that $\mathrm{CB} 2$ receptor blockade may enhance the inhibitory effects of $\mathrm{p}$-aminophenol on microglial activation. 


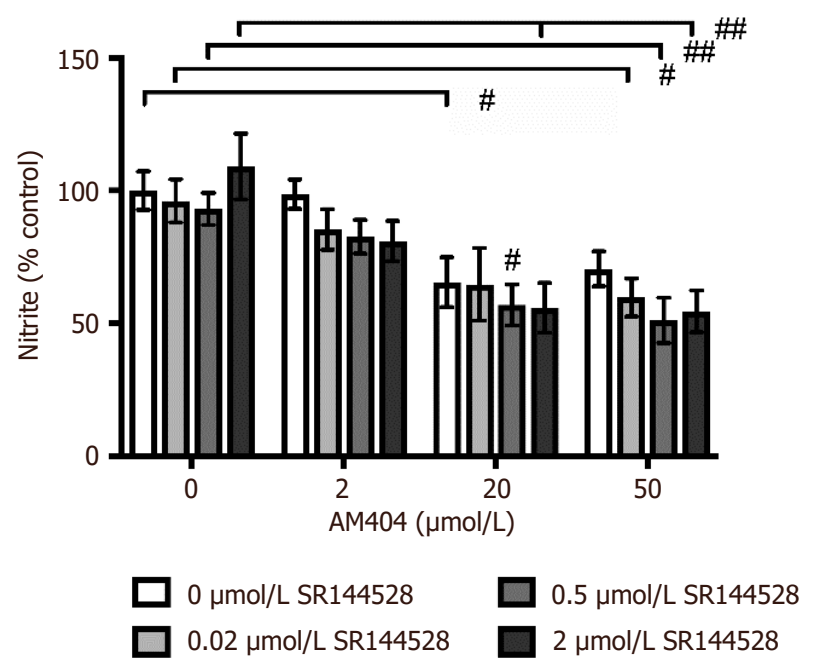

Figure 7. Effects of AM404 alone or in combination with the selective CB2 receptor antagonist SR144528 on lipopolysaccharide (LPS)induced nitric oxide release. BV-2 cells were treated for 15 min with various concentrations of SR144528 $(0.02,0.5,2 \mu \mathrm{mol} / \mathrm{L})$, then incubated with different concentrations $(2,20,50 \mu \mathrm{mol} / \mathrm{L})$ of AM404 for a further 15 min period, before being stimulated with LPS. After 24 h, nitrite concentrations in the BV-2 cell-free supernatants were measured using the Griess assay. Data from four independent experiments are normalized against nitrite concentration in samples stimulated in the absence of inhibitors. Nitrite concentration in these samples was $18.9 \pm 1.4 \mu \mathrm{mol} / \mathrm{L}$. The effect of treatments was assessed by the two-way analyses of variance (ANOVA), followed by Tukey's post hoc test. No significant differences were observed for stimulated cells incubated in the absence of SR144528 (ANOVA $F=1.56$, $P=0.21$ ). ${ }^{\#} P<0.05$ and ${ }^{\#} P<0.01$, significantly different from stimulated cells incubated in the absence of AM404 (ANOVA $F=22.23, P$ $<0.0001$ ). ANOVA interaction $F=0.45, P=0.90$

Subsequently, we studied whether p-aminophenol and AM404 suppress NO release from activated microglia through inhibition of COX-1 and COX-2. Involvement of COX was investigated because previous studies have demonstrated that AM404 modulates NO release as well as inhibits purified COX isoforms 1 and $2^{[23,27]}$. Furthermore, BV-2 cells express both isoforms of COX and these enzymes participate in inflammatory processes involving the AM404 precursor, arachidonic acid ${ }^{[59]}$. BV-2 cells were exposed for $15 \mathrm{~min}$ to various concentrations $(2,20,50 \mu \mathrm{mol} / \mathrm{L})$ of the nonselective COX inhibitor indomethacin prior to treatment with p-aminophenol or AM404 [Figures 8 and 9]. Previous reports have indicated that indomethacin is effective at inhibiting NO production by LPS-stimulated microglia in vitro ${ }^{[60]}$. We hypothesized that if p-aminophenol or AM404 lost their ability to inhibit NO release by stimulated microglia in the presence of indomethacin, it could be concluded that they exert their effect through COX inhibition. Consistent with the previous studies, indomethacin on its own significantly reduced NO production by stimulated BV-2 cells ${ }^{[60]}$. Both p-aminophenol and AM404 were able to attenuate NO secretion by stimulated microglia in the presence of indomethacin at all concentrations used. Notably, p-aminophenol and AM404 caused a greater reduction in NO secretion than indomethacin. While we cannot completely exclude COX inhibition as one of the mechanisms of p-aminophenol or AM404 inhibitory activity, it appears not to be the primary mechanism by which these compounds reduce microglial activation. It is important to note that, unlike other inhibitors used, indomethacin at $50 \mu \mathrm{mol} / \mathrm{L}$ was significantly toxic to BV-2 cells according to the LDH and MTT cell viability assays (data not shown), which could also be partially responsible for its inhibitory effect on NO production at this high concentration.

After determining that p-aminophenol and AM404 attenuate microglial activation independently of COX inhibition, we explored the effects of these compounds on TRPV1 signaling. TRPV 1 has been previously identified as a molecular target of AM404. Signaling through this receptor may contribute to the antiallodynic and antihyperalgesic effects of AM404, which are mediated by the NO pathway ${ }^{[23]}$. As such, we hypothesized that p-aminophenol and AM404 may reduce NO secretion from stimulated BV-2 microglia by interacting with TRPV ${ }^{[61]}$. BV-2 cells were treated for 15 min with various concentrations 


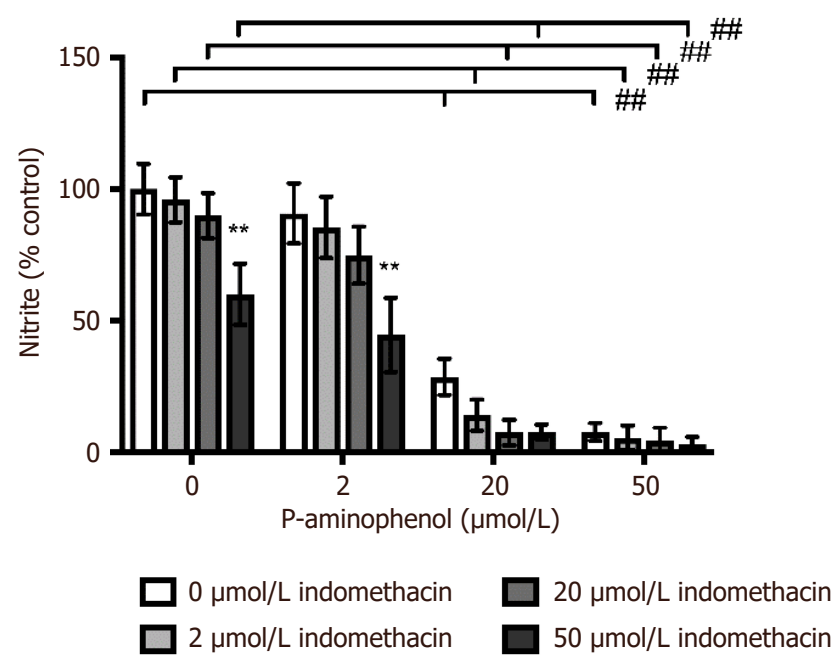

Figure 8. Effects of p-aminophenol alone or in combination with the non-selective cyclooxygenase inhibitor indomethacin on lipopolysaccharide (LPS)-induced nitric oxide release. BV-2 cells were treated for $15 \mathrm{~min}$ with various concentrations of indomethacin $(2,20,50 \mu \mathrm{mol} / \mathrm{L})$, then incubated with different concentrations $(2,20,50 \mu \mathrm{mol} / \mathrm{L})$ of $\mathrm{p}$-aminophenol for a further $15 \mathrm{~min}$ period, before being stimulated with LPS. After $24 \mathrm{~h}$, nitrite concentrations in the BV-2 cell-free supernatants were measured using the Griess assay. Data from four independent experiments are normalized against nitrite concentration in samples stimulated in the absence of inhibitors. Nitrite concentration in these samples was $27.1 \pm 2.6 \mu \mathrm{mol} / \mathrm{L}$. The effect of treatments was assessed by the two-way analyses of variance (ANOVA), followed by Tukey's post hoc test. ${ }^{\star \star} P<0.01$, significantly different from stimulated cells incubated in the absence of indomethacin (ANOVA $F=8.05, P=0.0002$ ); ${ }^{\# \#} P<0.01$, significantly different from stimulated cells incubated in the absence of p-aminophenol (ANOVA $F=95.51, P<0.0001$ ). ANOVA interaction $F=1.34, P=0.24$

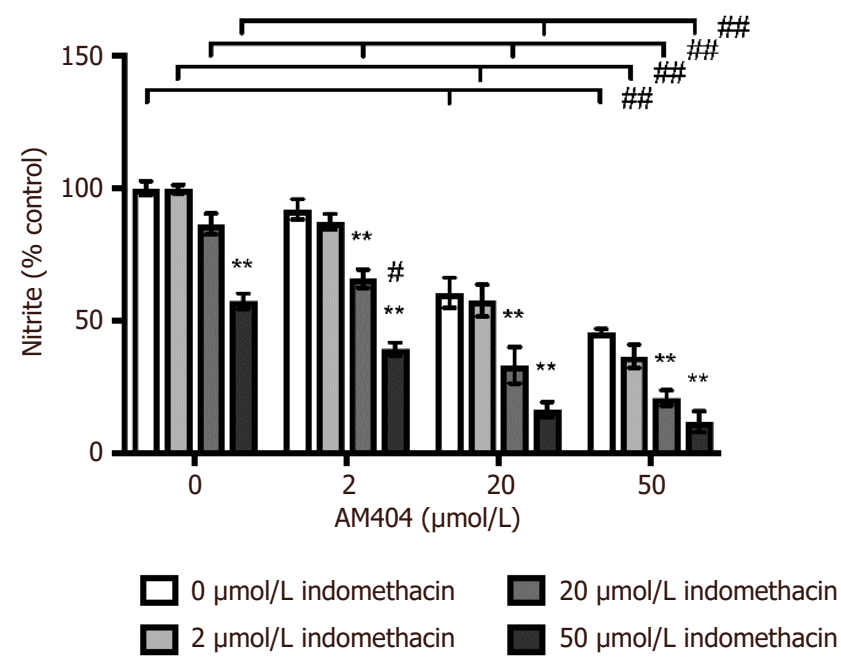

Figure 9. Effects of AM404 alone or in combination with the non-selective cyclooxygenase inhibitor indomethacin on lipopolysaccharide (LPS)-induced nitric oxide release. BV-2 cells were treated for $15 \mathrm{~min}$ with various concentrations of indomethacin $(2,20,50 \mu \mathrm{mol} / \mathrm{L})$, then incubated with different concentrations $(2,20,50 \mu \mathrm{mol} / \mathrm{L})$ of AM404 for a further 15 min period, before being stimulated with LPS. After 24 h, nitrite concentrations in the BV-2 cell-free supernatants were measured using the Griess assay. Data from four independent experiments are normalized against nitrite concentration in samples stimulated in the absence of inhibitors. Nitrite concentration in these samples was $26.6 \pm 0.7 \mu \mathrm{mol} / \mathrm{L}$. The effect of treatments was assessed by the two-way analyses of variance (ANOVA), followed by Tukey's post hoc test. ${ }^{\star \star} P<0.01$, significantly different from stimulated cells incubated in the absence of indomethacin (ANOVA $F=102.3$, $P<0.0001$ ); $\# P<0.05$ and ${ }^{\# \#} P<0.01$, significantly different from stimulated cells incubated in the absence of AM404 (ANOVA $F=179$, $P<0.0001$ ). ANOVA interaction $F=1.79, P=0.10$

$(0.02,0.5,2 \mu \mathrm{mol} / \mathrm{L})$ of the selective TRPV 1 antagonist BCTC to block signaling through this receptor prior to the addition of p-aminophenol or AM404. If BCTC reduces the inhibitory activity of p-aminophenol or AM404 on NO secretion from stimulated microglia, it could be concluded that these metabolites of acetaminophen exert their effect through TRPV1 signaling. Figures 10 and 11 illustrate that both 


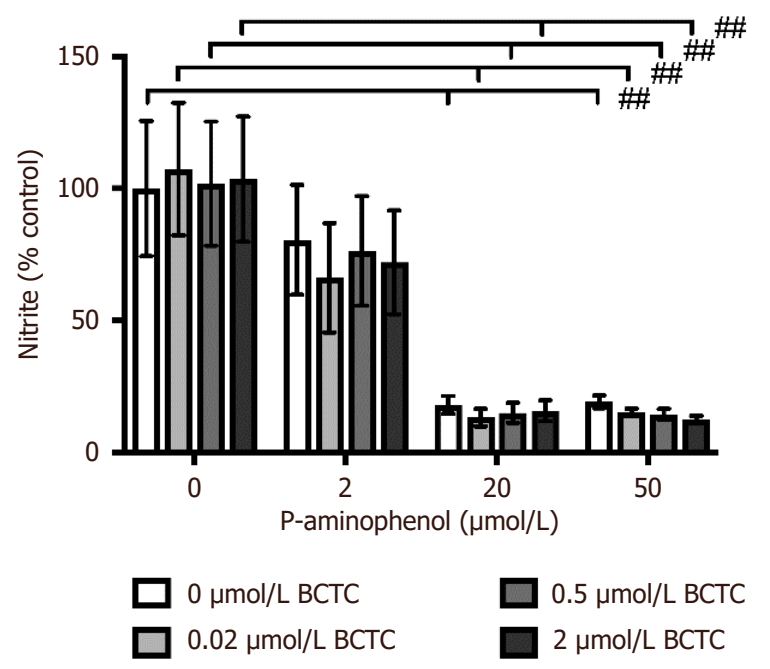

Figure 10. Effects of $p$-aminophenol alone or in combination with the TRPV1 antagonist BCTC on lipopolysaccharide (LPS)-induced nitric oxide release. BV-2 cells were treated for $15 \mathrm{~min}$ with various concentrations of BCTC $(0.02,0.5,2 \mu \mathrm{mol} / \mathrm{L})$, then incubated with different concentrations $(2,20,50 \mu \mathrm{mol} / \mathrm{L})$ of $\mathrm{p}$-aminophenol for a further $15 \mathrm{~min}$ period, before being stimulated with LPS. After $24 \mathrm{~h}$, nitrite concentrations in the BV-2 cell-free supernatants were measured using the Griess assay. Data from eight independent experiments are normalized against nitrite concentration in samples stimulated in the absence of inhibitors. Nitrite concentration in these samples was $9.4 \pm 2.4 \mu \mathrm{mol} / \mathrm{L}$. The effect of treatments was assessed by the two-way analyses of variance (ANOVA), followed by Tukey's post hoc test. No significant differences were observed for stimulated cells incubated in the absence of BCTC (ANOVA $F=0.049, P=0.99$ ). ${ }^{\# \#} P<0.01$, significantly different from stimulated cells incubated in the absence of $p$-aminophenol (ANOVA $F=29.65, P<0.0001$ ). ANOVA interaction $F=0.060$, $P=0.99$. BCTC: 4-(3-chloro-2-pyridinyl)-N-[4-(1,1-dimethylethyl)phenyl]-1-piperazinecarboxamide

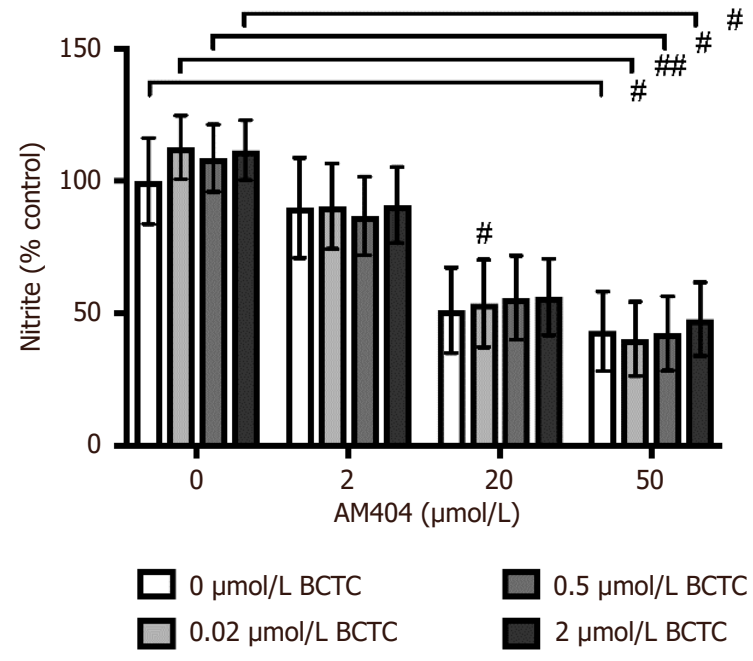

Figure 11. Effects of AM404 alone or in combination with the TRPV1 antagonist BCTC on lipopolysaccharide (LPS)-induced nitric oxide release. BV-2 cells were treated for 15 min with various concentrations of BCTC $(0.02,0.5,2 \mu \mathrm{mol} / \mathrm{L})$, then incubated with different concentrations $(2,20,50 \mu \mathrm{mol} / \mathrm{L})$ of AM404 for a further 15 min period, before being stimulated with LPS. After $24 \mathrm{~h}$, nitrite concentrations in the BV-2 cell-free supernatants were measured using the Griess assay. Data from five independent experiments are normalized against nitrite concentration in samples stimulated in the absence of inhibitors. Nitrite concentration in these samples was $16.5 \pm 2.7 \mu \mathrm{mol} / \mathrm{L}$. The effect of treatments was assessed by the two-way analyses of variance (ANOVA), followed by Tukey's post hoc test. No significant differences were observed for stimulated cells incubated in the absence of BCTC (ANOVA $F=0.096, P=0.96$ ). ${ }^{\#} P<0.05$ and ${ }^{\#} P<0.01$, significantly different from stimulated cells incubated in the absence of AM404 (ANOVA $F=16.45, P<0.0001$ ). ANOVA interaction $F=0.047, P=0.99$. BCTC: 4-(3-chloro-2-pyridinyl)-N-[4-(1,1-dimethylethyl)phenyl]-1-piperazinecarboxamide

p-aminophenol and AM404 attenuated NO secretion from activated BV-2 cells in the presence of BCTC at all concentrations used. BCTC on its own did not have a significant effect on the NO secretion by stimulated BV-2 microglia [Figures 10 and 11] or their viability (data not shown). 


\section{DISCUSSION}

Our data indicate that the inhibitory effect of p-aminophenol and AM404 on NO secretion by stimulated BV-2 microglia is not caused by COX inhibition, or interaction with CB2 or TRPV1 receptors. Furthermore, enzymatic conversion of p-aminophenol to AM404 by FAAH is not required for its pharmacological activity in BV-2 cell cultures. Stimulation of microglia with LPS has been shown to induce the expression of several genes that are regulated by mitogen-activated protein kinases (MAPKs) and NF$\kappa \mathrm{B}$, including such cytokines as TNF- $\alpha$, interleukin (IL)- $1 \beta$, interferon (IFN) $-\gamma$, and their receptors, as well as the stress proteins superoxide dismutase (SOD) 2, COX-2, and thioredoxin interacting protein ${ }^{[62,63]}$. Moreover, it has already been documented that stimulation of BV-2 murine microglia with LPS induces the expression of iNOS in a MAPK- and NF- $\kappa \mathrm{B}$-dependent manner ${ }^{[64-66]}$. Previous studies have also determined that AM404 prevents the activation of transcription factors NFAT and NF- $\kappa \mathrm{B}$ but preserves extracellular signal-regulated kinases (ERK) $1 / 2$ MAPK signaling in vivo ${ }^{[30,67]}$. Moreover, as NFAT is not directly activated by LPS, the only signaling pathway in this study that is both inhibited by AM404 and activated in microglia following stimulation with LPS is NF- $\kappa B^{[30,68]}$. AM404 has been shown to attenuate NF- $\kappa \mathrm{B}$ activation by inhibiting the phosphorylation, and subsequent degradation, of nuclear factor of kappa light polypeptide gene enhancer in B-cells inhibitor, alpha $\left(I_{\kappa} B \alpha\right)^{[30]}$. Intact $I_{\kappa} B \alpha$ sequesters NF- $\kappa B$ in the cytoplasm by interfering with the function of the nuclear localization signal, thereby blocking NF- $\kappa B$ gene activation ${ }^{[60]}$. Considering that NF- $\kappa \mathrm{B}$ activity is directly linked to the LPS-induced expression of iNOS and secretion of NO, it can be concluded that AM404 most likely modulates the secretion of NO from LPS-stimulated microglia through its inhibitory action on the NF- $\kappa \mathrm{B}$ pathway ${ }^{[70,71]}$. This conclusion is consistent with previous studies where AM404 was demonstrated to block the overexpression of iNOS in models of neuropathic pain, supporting a mechanism of AM404 action where it inhibits NO secretion at the transcription level ${ }^{[23,72]}$.

\section{DECLARATIONS}

\section{Authors' contributions}

Conceived the study and wrote the manuscript: Slattery WT, Klegeris A

Conducted experiments and analyzed the data: Slattery WT

\section{Data source and availability}

Data in this study were obtained by experimentation and are original. All primary data used to construct the summary figures are available by contacting the authors of this study.

\section{Financial support and sponsorship}

This work was supported by grants from the Natural Sciences and Engineering Research Council of Canada (NSERC) and the Jack Brown and Family Alzheimer's Disease Research Foundation.

\section{Conflicts of interest}

The authors declare that they have no conflicts of interest.

\section{Patient consent}

Not applicable.

\section{Ethics approval}

Not applicable.

\section{Copyright}

(c) The Author(s) 2018. 


\section{REFERENCES}

1. Drachman DA. The amyloid hypothesis, time to move on: amyloid is the downstream result, not cause, of Alzheimer's disease. Alzheimers Dement 2014;10:372-80.

2. Tuppo EE, Arias HR. The role of inflammation in Alzheimer's disease. Int J Biochem Cell Biol 2005;37:289-305.

3. Akiyama H, Barger S, Barnum S, Bradt B, Bauer J, Cole GM, Cooper NR, Eikelenboom P, Emmerling M, Fiebich BL, Finch CE, Frautschy S, Griffin WS, Hampel H, Hull M, Landreth G, Lue L, Mrak R, Mackenzie IR, McGeer PL, O’Banion MK, Pachter J, Pasinetti G, Plata-Salaman C, Rogers J, Rydel R, Shen Y, Streit W, Strohmeyer R, Tooyoma I, Van Muiswinkel FL, Veerhuis R, Walker D, Webster S, Wegrzyniak B, Wenk G, Wyss-Coray T. Inflammation and Alzheimer's disease. Neurobiol Aging 2000;21:383-421.

4. Heppner FL, Ransohoff RM, Becher B. Immune attack: the role of inflammation in Alzheimer disease. Nat Rev Neurosci 2015;16:35872.

5. Xu L, He D, Bai Y. Microglia-mediated inflammation and neurodegenerative disease. Mol Neurobiol 2015;53:6709-15.

6. Hornik TC, Vilalta A, Brown GC. Activated microglia cause reversible apoptosis of pheochromocytoma cells, inducing their cell death by phagocytosis. J Cell Sci 2016;129:65-79.

7. Shefa U, Yeo SG, Kim MS, Song IO, Jung J, Jeong NY, Huh Y. Role of gasotransmitters in oxidative stresses, neuroinflammation, and neuronal repair. Biomed Res Int 2017;2017:1689341.

8. Steinert JR, Chernova T, Forsythe ID. Nitric oxide signaling in brain function, dysfunction, and dementia. Neuroscientist 2010;16:43552.

9. Park TS, Ryu YK, Park HY, Kim JY, Go J, Noh JR, Kim YH, Hwang JH, Choi DH, Oh WK, Lee CH, Kim KS. Humulus japonicus inhibits the progression of Alzheimer's disease in a APP/PS1 transgenic mouse model. Int J Mol Med 2017;39:21-30.

10. Shi S, Liang D, Chen Y, Xie Y, Wang Y, Wang L, Wang Z, Qiao Z. Gx-50 reduces beta-amyloid-induced TNF-alpha, IL-1beta, NO, and PGE2 expression and inhibits NF-kappaB signaling in a mouse model of Alzheimer's disease. Eur J Immunol 2016;46:665-76.

11. Wu LY, Bao XQ, Pang HY, Sun H, Zhang D. FLZ attenuates learning and memory deficits via suppressing neuroinflammation induced by LPS in mice. J Asian Nat Prod Res 2015;17:306-17.

12. Lee YJ, Han SB, Nam SY, Oh KW, Hong JT. Inflammation and Alzheimer's disease. Arch Pharm Res 2010;33:1539-56.

13. Reinisch VM, Krause DL, Müller N. Neuroinflammation in Alzheimer's disease. In: Peterson PK, Toborek M, editors. Neuroinflammation and neurodegeneration. New York: Springer; 2014. p. 161-77.

14. Stewart WF, Kawas C, Corrada M, Metter EJ. Risk of Alzheimer's disease and duration of NSAID use. Neurology 1997;48:626-32.

15. Aisen PS, Schafer KA, Grundman M, Pfeiffer E, Sano M, Davis KL, Farlow MR, Jin S, Thomas RG, Thal LJ. Effects of rofecoxib or naproxen vs placebo on Alzheimer disease progression: a randomized controlled trial. JAMA 2003;289:2819-26.

16. Reines SA, Block GA, Morris JC, Liu G, Nessly ML, Lines CR, Norman BA, Baranak CC. Rofecoxib: no effect on Alzheimer's disease in a 1-year, randomized, blinded, controlled study. Neurology 2004;62:66-71.

17. Scharf S, Mander A, Ugoni A, Vajda F, Christophidis N. A double-blind, placebo-controlled trial of diclofenac/misoprostol in Alzheimer's disease. Neurology 1999;53:197-201.

18. Brune K, Renner B, Tiegs G. Acetaminophen/paracetamol: a history of errors, failures and false decisions. Eur J Pain 2015;19:953-65.

19. Fiebich BL, Lieb K, Hüll M, Aicher B, van Ryn J, Pairet M, Engelhardt G. Effects of caffeine and paracetamol alone or in combination with acetylsalicylic acid on prostaglandin E2 synthesis in rat microglial cells. Neuropharmacology 2000;39:2205-13.

20. Greco A, Ajmone-Cat MA, Nicolini A, Sciulli MG, Minghetti L. Paracetamol effectively reduces prostaglandin E2 synthesis in brain macrophages by inhibiting enzymatic activity of cyclooxygenase but not phospholipase and prostaglandin E synthase. $J$ Neurosci Res 2003;71:844-52.

21. Kis B, Snipes JA, Busija DW. Acetaminophen and the cyclooxygenase-3 puzzle: sorting out facts, fictions, and uncertainties. $J$ Pharmacol Exp Ther 2005;315:1-7.

22. Ottani A, Leone S, Sandrini M, Ferrari A, Bertolini A. The analgesic activity of paracetamol is prevented by the blockade of cannabinoid CB1 receptors. Eur J Pharmacol 2006;531:280-1.

23. Costa B, Siniscalco D, Trovato AE, Comelli F, Sotgiu ML, Colleoni M, Maione S, Rossi F, Giagnoni G. AM404, an inhibitor of anandamide uptake, prevents pain behaviour and modulates cytokine and apoptotic pathways in a rat model of neuropathic pain. $\mathrm{Br} J$ Pharmacol 2006;148:1022-32.

24. Mallet C, Daulhac L, Bonnefont J, Ledent C, Etienne M, Chapuy E, Libert F, Eschalier A. Endocannabinoid and serotonergic systems are needed for acetaminophen-induced analgesia. Pain 2008;139:190-200.

25. Jiang XL, Zhao P, Barrett JS, Lesko LJ, Schmidt S. Application of physiologically based pharmacokinetic modeling to predict acetaminophen metabolism and pharmacokinetics in children. CPT Pharmacometrics Syst Pharmacol 2013;2:e80.

26. Mazaleuskaya LL, Sangkuhl K, Thorn CF, FitzGerald GA, Altman RB, Klein TE. PharmGKB summary: pathways of acetaminophen metabolism at the therapeutic versus toxic doses. Pharmacogenet Genom 2015;25:416-26.

27. Högesätt ED, Bo AGJ, Ermund A, Andersson DA, Björk H, Alexander JP, Cravatt BF, Basbaum AI, Zygmunt PM. Conversion of acetaminophen to the bioactive $\mathrm{N}$-acylphenolamine AM404 via fatty acid amide hydrolase-dependent arachidonic acid conjugation in the nervous system. $J$ Biol Chem 2005;280:31405-12.

28. Chen C, Krausz KW, Idle JR, Gonzalez FJ. Identification of novel toxicity-associated metabolites by metabolomics and mass isotopomer analysis of acetaminophen metabolism in wild-type and Cyp2e1-null mice. J Biol Chem 2008;283:4543-59.

29. Newton JF, Kuo CH, DeShone GM, Hoefle D, Bernstein J, Hook JB. The role of p-aminophenol in acetaminophen-induced nephrotoxicity: effect of bis(p-nitrophenyl) phosphate on acetaminophen and p-aminophenol nephrotoxicity and metabolism in Fischer 344 rats. Tox Appl Pharmacol 1985;81:416-30. 
30. Caballero FJ, Soler-Torronteras R, Lara-Chica M, Garcia V, Fiebich BL, Munoz E, Calzado MA. AM404 inhibits NFAT and NF-kappa B signaling pathways and impairs migration and invasiveness of neuroblastoma cells. Eur J Pharmacol 2015;746:221-32.

31. Umathe SN, Manna SSS, Utturwar KS, Jain NS. Endocannabinoids mediate anxiolytic-like effect of acetaminophen via CB1 receptors. Prog Neuropsychopharmacol Biol Psychiatry 2009;33:1191-9.

32. Zaitone SA, El-Wakeil AF, Abou-El-Ela SH. Inhibition of fatty acid amide hydrolase by URB597 attenuates the anxiolytic-like effect of acetaminophen in the mouse elevated plus-maze test. Behav Pharmacol 2012;23:417-25.

33. Schultz S, DeSilva M, Gu TT, Qiang M, Whang K. Effects of the analgesic acetaminophen (paracetamol) and its para-aminophenol metabolite on viability of mouse-cultured cortical neurons. Bas Clin Pharmacol Toxicol 2012;110:141-4.

34. Farizatto KLG, McEwan SA, Naidoo V, Nikas SP, Shukla VG, Almeida MF, Byrd A, Romine H, Karanian DA, Makriyannis A, Bahr BA. Inhibitor of endocannabinoid deactivation protects against in vitro and in vivo neurotoxic effects of paraoxon. $J$ Mol Neurosci 2017;63:115-22.

35. Ding AH, Nathan CF, Stuehr DJ. Release of reactive nitrogen intermediates and reactive oxygen intermediates from mouse peritoneal macrophages. Comparison of activating cytokines and evidence for independent production. J Immunol 1988;141:2407-12.

36. Henn A, Lund S, Hedtjarn M, Schrattenholz A, Porzgen P, Leist M. The suitability of BV2 cells as alternative model system for primary microglia cultures or for animal experiments examining brain inflammation. ALTEX 2009;26:83-94.

37. Ivanov VM. The 125th Anniversary of the Griess Reagent. J Anal Chem 2004;59:1002-5.

38. Kelm M. Nitric oxide metabolism and breakdown. Biochi Biophys Acta 1999;1411:273-89.

39. Decker T, Lohmann-Matthes ML. A quick and simple method for the quantitation of lactate dehydrogenase release in measurements of cellular cytotoxicity and tumor necrosis factor (TNF) activity. J Immunol Methods 1988;115:61-9.

40. Mosmann T. Rapid colorimetric assay for cellular growth and survival: application to proliferation and cytotoxicity assays. J Immunol Methods 1983;65:55-63.

41. Fotakis G, Timbrell JA. In vitro cytotoxicity assays: comparison of LDH, neutral red, MTT and protein assay in hepatoma cell lines following exposure to cadmium chloride. Toxicol Lett 2006;160:171-7.

42. Lobner D. Comparison of the LDH and MTT assays for quantifying cell death: validity for neuronal apoptosis? $J$ Neurosci Methods 2000;96:147-52.

43. Stansley B, Post J, Hensley K. A comparative review of cell culture systems for the study of microglial biology in Alzheimer's disease. J Neuroinflammation 2012;9:115.

44. Brown GC. Nitric oxide and neuronal death. Nitric Oxide 2010;23:153-65.

45. Hwang SY, Jung JS, Lim SJ, Kim JY, Kim TH, Cho KH, Han IO. LY294002 inhibits interferon-gamma-stimulated inducible nitric oxide synthase expression in BV2 microglial cells. Biochem Biophys Res Commun 2004;318:691-7.

46. Kim JB, Sig Choi J, Yu YM, Nam K, Piao CS, Kim SW, Lee MH, Han PL, Park JS, Lee JK. HMGB1, a novel cytokine-like mediator linking acute neuronal death and delayed neuroinflammation in the postischemic brain. J Neurosci 2006;26:6413-21.

47. Mallet C, Barriere DA, Ermund A, Jonsson BAG, Eschalier A, Zygmunt PM, Hogestatt ED. TRPV1 in brain is involved in acetaminophen-induced antinociception. PLoS One 2010;5:e12748.

48. Tham CS, Whitaker J, Luo L, Webb M. Inhibition of microglial fatty acid amide hydrolase modulates LPS stimulated release of inflammatory mediators. FEBS Lett 2007;581:2899-904.

49. Jayamanne A, Greenwood R, Mitchell VA, Aslan S, Piomelli D, Vaughan CW. Actions of the FAAH inhibitor URB597 in neuropathic and inflammatory chronic pain models. Br J Pharmacol 2006;147:281-8.

50. Otrubova K, Ezzili C, Boger DL. The discovery and development of inhibitors of fatty acid amide hydrolase (FAAH). Bioorg Med Chem Lett 2011;21:4674-85.

51. Giuffrida A, Beltramo M, Piomelli D. Mechanisms of endocannabinoid inactivation: biochemistry and pharmacology. J Pharmacol Exp Ther 2001;298:7-14.

52. Rhoades KL, Golub SH, Economou JS. The regulation of the human tumor necrosis factor alpha promoter region in macrophage, $\mathrm{T}$ cell, and B cell lines. J Biol Chem 1992;267:22102-7.

53. Roche M, Kelly JP, O'Driscoll M, Finn DP. Augmentation of endogenous cannabinoid tone modulates lipopolysaccharide-induced alterations in circulating cytokine levels in rats. Immunology 2008;125:263-71.

54. Centonze D, Finazzi-Agrò A, Bernardi G, Maccarrone M. The endocannabinoid system in targeting inflammatory neurodegenerative diseases. Trends Pharmacol Sci 2007;28:180-7.

55. Klegeris A, Bissonnette CJ, McGeer PL. Reduction of human monocytic cell neurotoxicity and cytokine secretion by ligands of the cannabinoid-type CB2 receptor. Br J Pharmacol 2003;139:775-86.

56. Racz I, Nadal X, Alferink J, Banos JE, Rehnelt J, Martin M, Pintado B, Gutierrez-Adan A, Sanguino E, Bellora N, Manzanares J, Zimmer A, Maldonado R. Interferon-gamma is a critical modulator of $\mathrm{CB}(2)$ cannabinoid receptor signaling during neuropathic pain. $J$ Neurosci 2008;28:12136-45.

57. Franklin A, Stella N. Arachidonylcyclopropylamide increases microglial cell migration through cannabinoid CB2 and abnormalcannabidiol-sensitive receptors. Eur J Pharmacol 2003;474:195-8.

58. Fraga D, Raborn ES, Ferreira GA, Cabral GA. Cannabinoids inhibit migration of microglial-like cells to the HIV protein Tat. $J$ Neuroimmune Pharmacol 2011;6:566-77.

59. Kopalli SR, Koppula S. Carum carvi linn (umbelliferae) attenuates lipopolysaccharide-induced neuroinflammatory responses via regulation of NF-kappa B signaling in BV-2 microglia. Trop J Pharm Res 2015;14:1041-7.

60. Du ZY, Li XY. Inhibitory effects of indomethacin on interleukin-1 and nitric oxide production in rat microglia in vitro. Int $J$ Immunopharmacol 1999;21:219-25. 
61. Hassan S, Eldeeb K, Millns PJ, Bennett AJ, Alexander SPH, Kendall DA. Cannabidiol enhances microglial phagocytosis via transient receptor potential (TRP) channel activation. Br J Pharmacol 2014;171:2426-39.

62. Bode JG, Ehlting C, Häussinger D. The macrophage response towards LPS and its control through the p38MAPK-STAT3 axis. Cell Signal 2012;24:1185-94.

63. Sharif O, Bolshakov VN, Raines S, Newham P, Perkins ND. Transcriptional profiling of the LPS induced NF-kappa B response in macrophages. BMC Immunol 2007;8:1.

64. Subedi L, Ji E, Shin D, Jin J, Yeo JH, Kim SY. Equol, a dietary daidzein gut metabolite attenuates microglial activation and potentiates neuroprotection in vitro. Nutrients 2017;9:207.

65. Aktan F. iNOS-mediated nitric oxide production and its regulation. Life Sci 2004;75:639-53.

66. Oh WJ, Jung, U, Eom HS, Shin HJ, Park HR. Inhibition of lipopolysaccharide-induced proinflammatory responses by Buddleja officinalis extract in BV-2 microglial cells via negative regulation of NF-kB and ERK1/2 Signaling. Molecules 2013;18:9195-206.

67. Karanian DA, Brown QB, Makriyannis A, Kosten TA, Bahr BA. Dual modulation of endocannabinoid transport and fatty acid amide hydrolase protects against excitotoxicity. $J$ Neurosci 2005;25:7813-20.

68. Minematsu H, Shin MJ, Celil Aydemir AB, Kim KO, Nizami SA, Chung GJ, Lee FYI. Nuclear presence of nuclear factor of activated T cells (NFAT) c3 and c4 is required for Toll-like receptor-activated innate inflammatory response of monocytes/macrophages. Cell Signal 2011;23:1785-93.

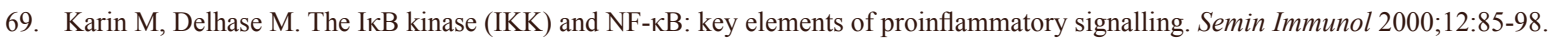

70. Liang YC, Huang YT, Tsai SH, Lin-Shiau SY, Chen CF, Lin JK. Suppression of inducible cyclooxygenase and inducible nitric oxide synthase by apigenin and related flavonoids in mouse macrophages. Carcinogenesis 1999;20:1945-52.

71. Barnes PJ, Karin M. Nuclear factor-kappaB: a pivotal transcription factor in chronic inflammatory diseases. $N$ Engl J Med 1997;336:1066-71.

72. La Rana G, Russo R, Campolongo P, Bortolato M, Mangieri RA, Cuomo V, Iacono A, Raso GM, Meli R, Piomelli D, Calignano A. Modulation of neuropathic and inflammatory pain by the endocannabinoid transport inhibitor AM404 [N-(4-Hydroxyphenyl)-eicosa5,8,11,14-tetraenamide]. J Pharmacol Exp Ther 2006;317:1365. 